\title{
Aeromonas encheleia sp. nov., Isolated from European Eels CONSUELO ESTEVE, ${ }^{1,2 *}$ M. CARMEN GUTIÉRREZ, ${ }^{2}$ AND ANTONIO VENTOSA ${ }^{2}$ Departamento de Microbiología y Ecología, Facultad de Ciencias Biológicas, Universitat de Valéncia, E-46100 Burjasot (Valencia), ${ }^{1}$ and Departamento de Microbiología y Parasitología, Facultad de Farmacia, Universidad de Sevilla, E-41012 Seville, ${ }^{2}$ Spain
}

\begin{abstract}
Four strains isolated from European eels in Valencia, Spain, were found to constitute a DNA relatedness group which is 0 to 50\% related to the 13 species and DNA group 11 of the genus Aeromonas. Phenotypically, these strains have all of the properties that define the genus Aeromonas. However, they differ from the previously described Aeromonas species by three or more properties. The strains are positive for motility, growth at $37^{\circ} \mathrm{C}$, indole production, and arginine dihydrolase activity. They exhibit negative reactions in tests for growth at $42^{\circ} \mathrm{C}$ and in thiosulfate-citrate-bile salts-sucrose medium (Oxoid), Simmons citrate tests, and tests for lysine and ornithine decarboxylase activities. They produce acid from salicin but not from L-arabinose, D-cellobiose, or lactose. All four strains hydrolyze esculin and arbutin but not elastin. They use L-serine as a sole carbon and energy source but cannot utilize L-arabinose, L-arginine, D-gluconate, or L-glutamine. The strains are resistant to ampicillin. The guanine-plus-cytosine content of the DNA is 59.4 to $60.8 \mathrm{~mol} \%$. The name Aeromonas encheleia sp. nov. is proposed for these strains; strain S181 (= CECT 4342) is the type strain. This new species is generally not pathogenic for eels or mice.
\end{abstract}

The genus Aeromonas was proposed by Kluyver and van Niel in 1936 (23) and comprises a collection of oxidase- and catalase-positive, glucose-fermenting, facultatively anaerobic, gram-negative, rod-shaped bacteria that are resistant to vibriostatic agent $\mathrm{O} / 129$ (2,4-diamino-6,7-diisopropyl pteridine) and generally are motile by means of polar flagella (32). Bergey's Manual of Systematic Bacteriology includes four species in the genus Aeromonas, Aeromonas salmonicida, Aeromonas hydrophila, Aeromonas caviae, and Aeromonas sobria, some of which are genotypically heterogeneous $(32,34)$. Recently, the number of recognized species in the genus Aeromonas has increased from 4 to 13 ; these species represent clearly differentiated DNA homology groups $(2,6,7,13,14,38-40)$. Furthermore, methods for identification of Aeromonas strains at the genus and species levels have undergone major improvements primarily as a result of chemotaxonomic studies $(3,4$, 20).

During a survey to determine what bacteria are associated with European eels reared in a freshwater farm located in Valencia, Spain, four phenotypically related strains were isolated. These strains could not be identified as members of any previously described Aeromonas species. The purposes of this study were to determine, by DNA-DNA hybridization and extensive phenotypic tests, the taxonomic position of the four eel isolates and to assess by inoculation in animal models the pathological significance of these organisms. In this paper we describe a new species, Aeromonas encheleia, which is generally not pathogenic for eels or mice.

\section{MATERIALS AND METHODS}

Bacterial strains. The four strains of $A$. encheleia used in this study (S176, $\mathrm{S} 177, \mathrm{~S} 181^{\mathrm{T}}[\mathrm{T}=$ type strain], and $\mathrm{S} 191$ ) were recovered from healthy European eels reared in a freshwater farm located in Valencia, Spain. Fifty juvenile eels (average weight, $0.3 \mathrm{~g}$ ) per tank were analyzed. The eels were washed by vigorous agitation in saline (Oxoid) and then homogenized in a fresh solution. Thus, strains S176, S177, S181 ${ }^{\mathrm{T}}$, and S191 were originally isolated from fish homogenates on tryptic soy agar (TSA) (Oxoid) supplemented with $0.5 \%$ (wt/vol) $\mathrm{NaCl}$. These four strains constituted a phenon defined at a level of similarity of $90.5 \%$ in a previous study (10), in which one of us (C.E.) used the simple matching coefficient followed by clustering of the operational taxonomic units into groups

* Corresponding author. by unweighted pair group mathematical averaging. The strains were maintained at $-80^{\circ} \mathrm{C}$ in a medium containing $1.7 \%(\mathrm{wt} / \mathrm{vol}$ ) tryptone (Oxoid), $0.3 \%(\mathrm{wt} / \mathrm{vol})$ soytone (Difco), $0.6 \%(\mathrm{wt} / \mathrm{vol})$ yeast extract (Oxoid), $1 \%(\mathrm{wt} / \mathrm{vol}) \mathrm{NaCl}(\mathrm{pH} 7.3)$, and $20 \%$ ( $\mathrm{vol} / \mathrm{vol}$ ) glycerol. The Aeromonas culture collection strains used in DNA relatedness experiments are listed in Table 1.

Physiological and biochemical characterization. Unless otherwise indicated, cultures were incubated at $28^{\circ} \mathrm{C}$. Cell shape and the Gram stain (9) reaction were determined after $24 \mathrm{~h}$ of incubation on TSA. Production of a diffusible brown pigment was determined with 7-day cultures on TSA plates. Motility was determined by microscopically examining 18 -h cultures in tryptic soy broth (Oxoid). The following tests were performed by using previously described methods (41) tests to determine Kovács cytochrome oxidase activity, reduction of nitrate and nitrite, catalase activity, gelatin liquefaction (method 1), and swarming. The tests used to determine susceptibility to vibriostatic agent $\mathrm{O} / 129(150-\mu \mathrm{g}$ discs; Oxoid), acetoin production (Voges-Proskauer test), lysine and ornithine decarboxylase and arginine dihydrolase activities (Moeller's method), salt tolerance $(0,3$, 6,8 , and $10 \%$ [wt/vol] $\mathrm{NaCl}$ ), and hydrolysis of esculin and arbutin were performed as described previously (24). Arginine dihydrolase activity was also tested by Thornley's method (42). The oxidation-fermentation test was performed by the method of Hugh and Leifson (15) in O/F basal medium (Difco) supplemented with $1 \%(\mathrm{wt} / \mathrm{vol})$ glucose. Production of gas from glucose was determined on tryptic soy broth, as described by Lee et al. (25). Production of indole and production of hydrogen sulfide were determined on sulfide indole motility medium (Difco) after $24 \mathrm{~h}$. Peptone water (1\% [wt/vol] peptone [Oxoid]) supplemented with $0.5 \%$ (wt/vol) tryptophan was also used to test indole production (41). Growth at different temperatures was determined in tryptic soy broth after $24 \mathrm{~h}$ for 37 and $40^{\circ} \mathrm{C}$, after 15 days for $15^{\circ} \mathrm{C}$, and after 21 days for $4^{\circ} \mathrm{C}$. Growth at $\mathrm{pH} 4.5$ and 9.0 was determined in tryptic soy broth after $48 \mathrm{~h}$. Growth on MacConkey medium (Oxoid) and growth on thiosulfate-citrate-bile salts-sucrose medium (Oxoid) were determined after $48 \mathrm{~h}$. Urease activity was determined in urea broth (Difco) incubated for $48 \mathrm{~h}$. Citrate utilization was determined on Simmons citrate agar (Oxoid). DNase activity was determined on DNase agar (Oxoid). The test to determine hydrolysis of chondroitin sulfate (Sigma) was performed by using previously described methods (21). Acid production from carbohydrates was determined on nutrient agar (Oxoid) supplemented with $0.001 \%$ (wt/vol) bromocresol purple and one of the following substrates (Sigma) at a concentration of $1 \%$ (wt/vol): L-arabinose, salicin, sucrose, D-cellobiose, D-xylose, maltose, D-melibiose, D-trehalose, D-galactose, lactose, D-raffinose, Dmannose, L-rhamnose, myo-erythritol, dulcitol, glycerol, myo-inositol, D-sorbitol, and D-mannitol. A yellow color around the growth after $48 \mathrm{~h}$ was recorded as a positive reaction. The tests to determine hydrolysis of starch, casein, and Tween 80 were performed as described previously (41). Hydrolysis of chitin (Sigma) was examined by the method of Reichenbach and Dworkin (36). The test to determine hydrolysis of collagen (Sigma) was performed in the medium of Gauthier et al. (12). The tests to determine lecithinase activity and hydrolysis of fibrinogen (Sigma) were performed as described by Janda and Bottone (17). Alkyl sulfatase activity was examined on TSA supplemented with $0.2 \%$ (wt/vol) sodium dodecyl sulfate (SDS) (Sigma); the method used was similar to that described by Kitaura et al. (22). Hydrolysis of mucin (Sigma) and hydrolysis of keratin were determined as described previously $(29,44)$. The test to determine hydrolysis of elastin (Sigma) was performed on modified Scharman medium (16). Hemolytic activity against human erythrocytes was determined on TSA supplemented with $5 \%$ 
TABLE 1. Levels of DNA relatedness of strains $\mathrm{S} 181^{\mathrm{T}}$ and S176 to other $A$. encheleia strains, strains of other Aeromonas species, and related bacteria

\begin{tabular}{|c|c|c|}
\hline \multirow{2}{*}{ Source of unlabeled $\mathrm{DNA}^{a}$} & \multicolumn{2}{|c|}{$\begin{array}{l}\text { \% Homology with } \\
{ }^{3} \mathrm{H} \text {-labeled DNA from: }\end{array}$} \\
\hline & $\begin{array}{l}\text { A. encheleia } \\
\mathrm{S} 181^{\mathrm{T}}\end{array}$ & $\begin{array}{l}\text { A. encheleia } \\
\text { S176 }\end{array}$ \\
\hline \multicolumn{3}{|l|}{ A. encheleia strains } \\
\hline $\mathrm{S} 181^{\mathrm{T}}$ & 100 & 70 \\
\hline S176 & 86 & 100 \\
\hline S177 & 70 & 88 \\
\hline S191 & 88 & 92 \\
\hline A. hydrophila ATCC $7966^{\mathrm{T}}$ (DNA group 1) & 27 & 25 \\
\hline \multicolumn{3}{|l|}{$\begin{array}{l}\text { A. salmonicida subsp. salmonicida (DNA } \\
\text { group 3) strains }\end{array}$} \\
\hline NCIMB $1102^{\mathrm{T}}$ & 49 & 46 \\
\hline ATCC 14174 & 45 & 0 \\
\hline A. caviae ATCC $15468^{\mathrm{T}}$ (DNA group 4 ) & 29 & $\mathrm{ND}^{b}$ \\
\hline A. media ATCC $33907^{\mathrm{T}}$ (DNA group 5b) & 6 & 50 \\
\hline A. eucrenophila NCIMB $74^{\mathrm{T}}$ (DNA group 6) & 7 & ND \\
\hline A. sobria CIP $74.33^{\mathrm{T}}$ (DNA group 7 ) & 48 & 3 \\
\hline $\begin{array}{l}\text { A. veronii bv. sobria (DNA group 8/10) strain } \\
\text { ATCC } 9071\end{array}$ & 40 & 6 \\
\hline $\begin{array}{l}\text { A. veronii bv. veronii (DNA group 8/10) } \\
\text { strain ATCC } 35624^{\mathrm{r}}\end{array}$ & 19 & 34 \\
\hline A. jandaei ATCC $49568^{\mathrm{T}}$ (DNA group 9) & 0 & 2 \\
\hline $\begin{array}{l}\text { Aeromonas sp. strain ATCC } 35941 \text { (DNA } \\
\text { group 11) }\end{array}$ & 12 & 37 \\
\hline A. schubertii ATCC $43700^{\mathrm{T}}$ (DNA group 12) & 0 & 0 \\
\hline A. trota ATCC $49657^{\mathrm{T}}$ (DNA group 13 ) & 0 & 0 \\
\hline $\begin{array}{l}\text { Aeromonas sp. strain ATCC } 43946 \text { (enteric } \\
\text { group 501) }\end{array}$ & 3 & 16 \\
\hline A. ichthiosmia DSM $6393^{\mathrm{T}}$ & 9 & 20 \\
\hline A. enteropelogenes DSM $6394^{\mathrm{T}}$ & 3 & 7 \\
\hline \multicolumn{3}{|l|}{ A. allosaccharophila strains } \\
\hline CECT $4199^{\frac{1}{T}}$ & 0 & 6 \\
\hline 290 & 17 & 0 \\
\hline ATCC 35942 & 1 & 24 \\
\hline
\end{tabular}

${ }^{a}$ ATCC, American Type Culture Collection, Rockville, Md.; CECT, Colección Española de Cultivos Tipo, Valencia, Spain; CIP, Collection de l'Institut Pasteur, Paris, France; DSM, Deutsche Sammlung von Mikroorganismen und Zellkulturen GmbH, Braunschweig, Germany; NCIMB, National Collection of Industrial and Marine Bacteria, Aberdeen, Scotland.

${ }^{b} \mathrm{ND}$, not determined.

(vol/vol) washed blood (43). Utilization of several carbon sources was examined by using the basal medium described by Lee et al. (25) supplemented with $1 \%$ (wt/vol) purified agar (Oxoid) and either a sugar at a concentration of $0.2 \%$ $(\mathrm{wt} / \mathrm{vol})$ or another substrate at a concentration of $0.1 \%$ (wt/vol). The carbon sources which we used were obtained from Sigma and included L-arabinose, salicin, D-cellobiose, sucrose, L-rhamnose, lactose, maltose, D-mannose, D-trehalose, D-galactose, D-raffinose, L-histidine, L-arginine, L-citrulline, L-leucine, Lalanine, glycine, L-proline, L-serine, L-glutamine, L-tyrosine, L-glutamate, L-aspartate, DL-3-hydroxybutyrate, propionate, $\gamma$-aminobutyrate, D-gluconate, D-glucuronate, L-malate, $\alpha$-ketoglutarate, fumarate, succinate, ethanol, myo-inositol, D-mannitol, myo-erythritol, dulcitol, putrescine, and glycerol. Susceptibility to antibacterial compounds was determined on TSA supplemented with the following substances: amikacin ( $25 \mathrm{mg} /$ liter), streptomycin ( $25 \mathrm{mg} / \mathrm{liter})$, gentamicin (10 mg/liter), kanamycin ( $50 \mathrm{mg} /$ liter), tobramycin ( $25 \mathrm{mg} /$ liter), penicillin V (10 mg/liter), ampicillin ( $50 \mathrm{mg} /$ liter), amoxicillin (50 mg/liter), carbenicillin (100 mg/liter), erythromycin (15 mg/liter), nitrofurantoin (10 mg/liter), oxolinic acid (10 mg/liter), nalidixic acid (50 mg/liter), polymyxin B (300 U/liter), rifampin (30 mg/liter), sulfanilamide ( $300 \mathrm{mg} /$ liter), sulfadimethoxine (12 mg/liter), tetracycline (15 mg/liter), chloramphenicol ( $25 \mathrm{mg} /$ /iter), phosphomycin ( $50 \mathrm{mg} / \mathrm{liter}$ ), novobiocin ( $5 \mathrm{mg} / \mathrm{liter})$, and trimethoprim $(25 \mathrm{mg} / \mathrm{liter})$.

Pathogenicity. The virulence of strains S181 ${ }^{\mathrm{T}}, \mathrm{S} 176$, and S191 for eels and mice was also examined. Juvenile European eels ( 5 to $12 \mathrm{~g}$ ) and 6-week-old mice (19 to $31 \mathrm{~g}$ ) were used in the infection trials. For each strain, six animals were injected intraperitoneally with $0.1 \mathrm{ml}$ of a suspension containing from $10^{10}$ to $10^{4}$ cells per $\mathrm{ml}$ in phosphate-buffered saline (PBS) (Oxoid), and then they were kept separately in a laboratory. Six animals injected with $0.1 \mathrm{ml}$ of PBS were kept under the same conditions. Mortality was recorded daily for 7 days. The $50 \%$ lethal doses $\left(\mathrm{LD}_{50}\right)$ of bacterial cells were calculated as described previously
TABLE 2. $T_{m}$ values and DNA base compositions of A. encheleia strains and E. coli NCTC $9001^{a}$

\begin{tabular}{lcc}
\hline \multicolumn{1}{c}{ Strain } & $T_{m}\left({ }^{\circ} \mathrm{C}\right)^{b}$ & $\mathrm{G}+\mathrm{C}$ content (mol\%) \\
\hline A. encheleia S181 & $79.0 \pm 0.3$ & 60.0 \\
A. encheleia S176 & $78.8 \pm 0.5$ & 59.5 \\
A. encheleia S177 & $78.7 \pm 0.2$ & 59.4 \\
A. encheleia S191 & $79.4 \pm 0.1$ & 60.8 \\
E. coli NCTC 9001 & $74.6 \pm 0.05^{c}$ & $50.9^{d}$ \\
\hline
\end{tabular}

${ }^{a}$ NCTC, National Collection of Type Cultures, Colindale, London, England.

${ }^{b}$ Mean \pm standard deviation. The means are averages of the values from three or more separate determinations in $0.1 \times$ SSC buffer.

${ }^{c}$ The previously reported $T_{m}$ value is $74.6^{\circ} \mathrm{C}(31)$.

${ }^{d}$ The previously reported $\mathrm{G}+\mathrm{C}$ content is $50.9 \mathrm{~mol} \%$ (31).

(35). Strains that had an $\mathrm{LD}_{50}$ of $\geq 10^{8}$ cells per fish or mouse were considered avirulent, as described by Santos et al. (37) and Janda and Kokka (18).

DNA-DNA hybridization. Previously described procedures were used to extract, purify, and shear unlabeled DNAs $(19,26)$. The competitive nitrocellulose filter method was used for DNA hybridization (19). Experiments were performed three times. DNAs from strains $S 181^{\mathrm{T}}$ and $\mathrm{S} 176$ were nick translated with $\left[{ }^{3} \mathrm{H}\right]$ dCTP (catalog no. RPN 1601Y; Amersham International, Amersham, United Kingdom) and reacted with unlabeled competitor DNAs from other Aeromonas strains at a reassociation temperature of 55.5 to $56.0^{\circ} \mathrm{C}$. The hybridization mixtures contained $30 \%$ formamide (Sigma). The ratio of the concentration of competitor DNA to concentration of labeled DNA was at least 150:1. The percentages of homology were calculated as described previously (19).

DNA base composition. The $\mathrm{G}+\mathrm{C}$ contents of the DNAs of strains $\mathrm{S} 181^{\mathrm{T}}$, S176, S177, and S191 were determined from the midpoints $\left(T_{m}\right)$ of the thermal denaturation profiles $(11,27,30)$. The $T_{m}$ of Escherichia coli NCTC 9001 DNA was determined experimentally and was used as a reference.

\section{RESULTS AND DISCUSSION}

The phenotypic properties common to strains $\mathrm{S} 181^{\mathrm{T}}, \mathrm{S} 176$, $\mathrm{S} 177$, and S191 are given in the species description below.

Identification to the genus level. The four strains isolated from eels have the phenotypic characteristics of the genus Aeromonas (32). The cells are gram negative, motile, and rod shaped with rounded ends, and they occur singly, in pairs, or in short chains. The strains are facultative anaerobes, and most strains produce acid and gas from glucose under anaerobic conditions (the exception is strain S177, which does not produce gas from glucose). The strains are oxidase and catalase positive, reduce nitrate to nitrite, and are resistant to vibriostatic agent $\mathrm{O} / 129$. The strains use D-mannitol and exhibit gelatinase, DNase, and Tween 80 esterase activities. The strains do not produce acid from xylose, dulcitol, and myoinositol. The strains do not produce hydrogen sulfide from thiosulfate and do not require sodium ions for growth. The $\mathrm{G}+\mathrm{C}$ contents of the DNAs of strains $\mathrm{S} 181^{\mathrm{T}}, \mathrm{S} 176, \mathrm{~S} 177$, and S191 range from 59.4 to $60.8 \mathrm{~mol} \%$ (Table 2). These values are within the range reported for the genus Aeromonas (57 to 59 mol\% for $A$. salmonicida [32] and 58 to $63 \mathrm{~mol} \%$ for the mesophilic Aeromonas species [2, 14, 32, 38-40]).

DNA relatedness. The levels of DNA relatedness of strains $\mathrm{S} 181^{\mathrm{T}}$ and S176 to three other strains isolated from eels, 13 Aeromonas species, the Aeromonas DNA group 11 reference strain, and Aeromonas sp. strain ATCC 43946 (enteric group 501) are shown in Table 1. The Aeromonas species and hybridization groups included in the study were 0 to $50 \%$ related to strains $\mathrm{S} 181^{\mathrm{T}}$ and S176. The four strains isolated from eels $\left(\mathrm{S} 181^{\mathrm{T}}, \mathrm{S} 176, \mathrm{~S} 177\right.$, and S191) constituted a tight DNA genomic species (levels of DNA homology, $\geq 70 \%$ ) distinct from previously described Aeromonas species.

Pathogenicity. Strains S181 T, S176, S177, and S191 were isolated in December 1987 from healthy eels. The previous and subsequent epizootic outbreaks at the eel farm occurred in August 1987 and March 1988, respectively. Infection trials in 
TABLE 3. Characteristics useful for distinguishing $A$. encheleia from previously described mesophilic Aeromonas species

\begin{tabular}{|c|c|c|c|c|c|c|c|c|c|c|c|c|c|c|}
\hline \multirow{2}{*}{ Species } & \multirow{2}{*}{ Motility } & \multirow{2}{*}{ Indole } & \multirow{2}{*}{$\begin{array}{l}\text { Gas } \\
\text { produced } \\
\text { from } \\
\text { glucose }\end{array}$} & \multicolumn{2}{|c|}{$\begin{array}{l}\text { Acid produced } \\
\text { from: }\end{array}$} & \multirow{2}{*}{$\begin{array}{c}\text { Ornithine } \\
\text { decarboxy- } \\
\text { lase } \\
\text { activity }\end{array}$} & \multicolumn{4}{|c|}{ Use of: } & \multirow{2}{*}{$\begin{array}{l}\text { Growth } \\
\text { at } 42^{\circ} \mathrm{C}\end{array}$} & \multicolumn{3}{|c|}{ Hydrolysis of: } \\
\hline & & & & Salicin & Cellobiose & & Gluconate & Arginine & Glutamine & Arabinose & & Elastin & Esculin & Arbutin \\
\hline A. encheleia & $+^{a}$ & + & d & + & - & - & - & - & - & - & - & - & + & + \\
\hline A. hydrophila ${ }^{b}$ & + & + & + & d & d & - & + & + & d & + & d & + & + & + \\
\hline A. caviae & + & + & - & + & $\mathrm{d}$ & - & + & + & + & + & $\mathrm{d}$ & - & + & + \\
\hline A. media $^{c}$ & - & + & $-d$ & + & + & - & + & + & + & $\mathrm{d}$ & $\mathrm{d}$ & - & + & + \\
\hline A. eucrenophila & + & $+^{d}$ & + & $+^{d}$ & $+^{d}$ & $-d$ & $t^{d}$ & + & $+^{d}$ & $+^{d}$ & - & + & + & $-{ }^{d}$ \\
\hline A. sobria ${ }^{b}$ & + & + & + & - & $\mathrm{d}$ & - & + & - & $-{ }^{d}$ & - & $\mathrm{d}$ & $\mathrm{d}$ & $\mathrm{d}$ & - \\
\hline A. veronii bv. veroniif & + & + & + & + & $\mathrm{d}$ & + & + & + & + & - & + & - & + & $\mathrm{d}$ \\
\hline A. veronii bv. sobria ${ }^{g}$ & $\mathrm{~d}$ & + & + & - & ND & - & ND & ND & ND & ND & + & ND & - & - \\
\hline A. jandaei ${ }^{h}$ & + & + & + & - & $\mathrm{d}$ & - & d & $\mathrm{d}$ & $\mathrm{d}$ & - & + & $\mathrm{d}$ & - & - \\
\hline A. trota $^{i}$ & + & + & + & - & + & - & $++^{d}$ & $+^{d}$ & $+^{d}$ & $-d$ & + & - & - & d \\
\hline A. allosaccharophila ${ }^{j}$ & + & + & + & - & + & d & + & + & $\mathrm{d}$ & + & + & - & d & - \\
\hline A. enteropelogenes ${ }^{k}$ & + & + & + & ND & ND & - & ND & ND & ND & ND & ND & ND & - & - \\
\hline A. ichthiosmial & + & + & + & ND & $\mathrm{d}$ & - & ND & ND & ND & ND & - & ND & - & - \\
\hline
\end{tabular}

$a+, 90 \%$ or more of the strains are positive;,$- 90 \%$ or more of the strains are negative; $d, 11$ to $89 \%$ of the strains are positive; ND, no data available.

${ }^{b}$ Data from references $5,8,10$, and 33 .

${ }^{c}$ Data from references 2,5 , and 10 .

${ }^{d}$ Results obtained with the type strain of the species.

${ }^{e}$ Data from references 10 and 38.

$f$ Data from references 8,10 , and 14 .

${ }^{g}$ Data from references 1 and 8 .

${ }^{h}$ Data from references 7,8 , and 10 .

${ }^{i}$ Data from references 6,8 , and 10.

${ }^{j}$ Data from reference 28 .

${ }^{k}$ Data from reference 39.

${ }^{l}$ Data from reference 40.

${ }^{m}$ Data from references 8,10 , and 13 .

which we injected bacterial cells intraperitoneally into healthy eels showed that strains $\mathrm{S} 181^{\mathrm{T}}$, S177, and $\mathrm{S} 191$ were avirulent for eels $\left(\mathrm{LD}_{50}, 4.5 \times 10^{8}\right.$ to $6.3 \times 10^{8}$ cells per fish), whereas strain $\mathrm{S} 176$ was weakly virulent for eels $\left(\mathrm{LD}_{50}, 1.7 \times 10^{7}\right.$ cells per fish). The fact that strains S181 ${ }^{\mathrm{T}}, \mathrm{S} 176, \mathrm{~S} 177$, and S191 were not related to epizootic outbreaks and the fact that they were avirulent or weakly virulent for eels suggest that they are members of the saprophytic microbial community associated with European eels. On the other hand, all of these strains were avirulent for mice $\left(\mathrm{LD}_{50}, 1.0 \times 10^{8}\right.$ to $1.8 \times 10^{8}$ cells per mouse).

Phenotypic differentiation of the new genomic species. The strains isolated from eels (S181 ${ }^{\mathrm{T}}, \mathrm{S} 176, \mathrm{~S} 177$, and S191) are readily distinguished from $A$. salmonicida by their motility and their ability to grow in broth at $37^{\circ} \mathrm{C}$. The major characteristics that differentiate the new genomic species from other mesophilic Aeromonas species are shown in Table 3. The eel isolates differ from the previously described mesophilic Aeromonas species by their inability to use D-gluconate as a sole carbon and energy source. All of the esculin-positive Aeromonas species (A. hydrophila, A. caviae, Aeromonas media, Aeromonas eucrenophila, and Aeromonas veronii bv. veronii) are able to use L-arginine and L-glutamine, but the strains isolated from eels are not. In addition, $A$. hydrophila hydrolyzes elastin; $A$. media is nonmotile and produces acid from D-cellobiose; $A$. eucrenophila hydrolyzes elastin but not arbutin and produces acid from D-cellobiose; and $A$. veronii bv. veronii exhibits ornithine decarboxylase activity and grows in broth at $42^{\circ} \mathrm{C}$. $A$. veronii bv. sobria, Aeromonas jandaei, Aeromonas trota, Aeromonas enteropelogenes, Aeromonas ichthiosmia, and Aeromonas schubertii differ from the eel isolates by failing to hydrolyze esculin and arbutin. In addition, $A$. veronii bv. sobria and $A$. jandaei grow at $42^{\circ} \mathrm{C}$ but do not produce acid from salicin; $A$. trota also produces acid from D-cellobiose; and $A$. schubertii is also elastase positive. Aeromonas allosaccharophila is easily distinguished from the eel isolates by the following characteristics: acid is produced from salicin and D-cellobiose, arbutin is hydrolyzed, L-arginine and L-arabinose are utilized, and growth occurs at $42^{\circ} \mathrm{C}$. $A$. sobria differs from the eel isolates by its inability to hydrolyze arbutin and its inability to produce acid from salicin.

Since strains $\mathrm{S} 181^{\mathrm{T}}, \mathrm{S} 176, \mathrm{~S} 177$, and S191 constitute a genomic species that can be identified by phenotypic properties, they represent a new species (45), for which we propose the name Aeromonas encheleia.

Description of Aeromonas encheleia sp. nov. Aeromonas encheleia (en.che'le.ia. Gr. n. enchelys, eel; M. L. adj. encheleia, from eels). Gram-negative, straight, motile rods. Colonies develop within $24 \mathrm{~h}$ at $28^{\circ} \mathrm{C}$ on TSA (Oxoid) and are not pigmented. Old cultures (10 to 15 days), however, contain colonies with light brown pigmented centers. No brown watersoluble pigment is produced. Growth occurs on MacConkey agar but not on thiosulfate-citrate-bile salts-sucrose agar. Chemoorganotrophic, with both oxidative and fermentative metabolism. Acid is produced from glucose. Three of the four strains produce gas from glucose (Table 4). Oxidase and catalase positive. Reduces nitrate to nitrite. Resistant to vibriostatic agent $\mathrm{O} / 129$. Growth occurs in the presence of 0 to $3 \%$ (wt/vol) $\mathrm{NaCl}$, at temperatures between 4 and $37^{\circ} \mathrm{C}$, and under alkaline (pH 9.0) conditions. Arginine dihydrolase and indole positive. $\mathrm{H}_{2} \mathrm{~S}$ and lysine and ornithine decarboxylase negative. Three of the four strains are Voges-Proskauer negative (Table 4).

Acid is produced from salicin, maltose, D-mannose, D-trehalose, D-galactose, and D-mannitol, but not from L-arabinose, D-cellobiose, lactose, D-xylose, D-melibiose, D-raffinose, myoerythritol, dulcitol, myo-inositol, or D-sorbitol. Three of the four strains produce acid from sucrose and L-rhamnose but not from glycerol (Table 4). 
TABLE 4. Characteristics of $A$. encheleia which differ from strain to strain

\begin{tabular}{|c|c|c|}
\hline Characteristic & $\begin{array}{l}\text { No. of strains } \\
\text { positive }\end{array}$ & $\begin{array}{l}\text { Reaction of } \\
\text { strain } S 181^{\mathrm{T}}\end{array}$ \\
\hline Gas produced from glucose & $3(75)^{a}$ & $+^{b}$ \\
\hline Voges-Proskauer reaction & $1(25)$ & - \\
\hline \multicolumn{3}{|l|}{ Acid produced from: } \\
\hline Sucrose & $3(75)$ & + \\
\hline L-Rhamnose & $3(75)$ & + \\
\hline Glycerol & $1(25)$ & - \\
\hline \multicolumn{3}{|l|}{ Utilization of ${ }^{c}$ : } \\
\hline D-Galactose & $1(25)$ & - \\
\hline L-Histidine & $3(75)$ & + \\
\hline L-Glutamate & $1(25)$ & - \\
\hline$\gamma$-Aminobutyrate & $1(25)$ & + \\
\hline Succinate & $2(50)$ & + \\
\hline Glycerol & $2(50)$ & + \\
\hline \multicolumn{3}{|l|}{ Hydrolysis of: } \\
\hline Mucin & $1(25)$ & - \\
\hline Fibrinogen & $3(75)$ & + \\
\hline Starch & $3(75)$ & + \\
\hline
\end{tabular}

${ }^{a}$ The numbers in parentheses are percentages.

$b+$, positive; - , negative.

${ }^{c}$ Utilization as sole sources of carbon and energy.

The strains hydrolyze esculin, arbutin, gelatin, casein, collagen, chitin, Tween 80 , egg yolk, and DNA, but not chondroitin sulfate, elastin, keratin, or urea. SDS-alkyl sulfatase negative. Three of the four strains hydrolyze fibrinogen and starch but not mucin (Table 4). Human erythrocytes are hemolyzed.

All $A$. encheleia strains use the following substrates as sole carbon and energy sources: sucrose, salicin, maltose, D-mannose, D-trehalose, L-proline, L-serine, L-malate, fumarate, and D-mannitol. Three of the four strains utilize L-hystidine (Table 4). None of the strains uses the following substrates as sole carbon and energy sources: L-arabinose, D-cellobiose, L-rhamnose, lactose, D-raffinose, L-arginine, L-citrulline, L-leucine, Lalanine, glycine, L-glutamine, L-tyrosine, citrate, L-aspartate, DL-3-hydroxybutyrate, propionate, D-gluconate, D-glucuronate, $\alpha$-ketoglutarate, myo-inositol, myo-erythritol, dulcitol, ethanol, and putrescine. Three of the four strains do not utilize Lglutamate and D-galactose (Table 4).

Susceptible to amikacin, streptomycin, gentamicin, kanamycin, tobramycin, erythromycin, nitrofurantoin, nalidixic acid, oxolinic acid, polymyxin B, rifampin, tetracycline, and chloramphenicol. Resistant to penicillin V, ampicillin, amoxicillin, carbenicillin, sulfanilamide, sulfadimethoxine, phosphomycin, novobiocin, and trimethoprim. Additional characteristics which vary among strains are shown in Table 4.

The $\mathrm{G}+\mathrm{C}$ content is 59.4 to $60.8 \mathrm{~mol} \%$ as determined by the $T_{m}$ method.

Isolated from healthy European eels (Anguilla anguilla) reared in a freshwater farm located in Valencia, Spain. Mostly avirulent for eels. Not pathogenic for mice, which are currently used to assess pathological significance for humans.

The type strain is strain S181.

Description of the type strain. Strain $\mathrm{S} 181^{\mathrm{T}}$ has all of the properties given above for the species. In addition, gas is produced from glucose, acid is produced from sucrose and Lrhamnose, and the organism utilizes L-histidine, $\gamma$-aminobutyrate, succinate, and glycerol and hydrolyzes starch and fibrinogen (Table 4). Also, the Voges-Proskauer reaction is negative, acid is not produced from glycerol, mucin is not hydrolyzed, and D-galactose and L-glutamate are not utilized (Table 4). The G+C content of the DNA is $60.0 \mathrm{~mol} \%$. This strain has been deposited in the Colección Española de Cultivos Tipo, Valencia, Spain, as strain CECT 4342.

\section{ACKNOWLEDGMENTS}

C. Esteve thanks the Ministerio de Educación y Ciencia (Spanish Government) and the Consellería de Cultura (Generalitat Valenciana) for predoctoral and postdoctoral research fellowships, respectively. This work was supported in part by grants from the Ministerio de Educación y Ciencia (Dirección General de Investigación Científica y Técnica grants PB92-0670 and PB93-0920) and from the Junta de Andalucía.

We thank D. García and C. Belloch for technical assistance.

\section{REFERENCES}

1. Abbott, S. L., W. K. W. Cheung, S. Kroske-Bystrom, T. Malekzadeh, and J. M. Janda. 1992. Identification of Aeromonas strains to the genospecies level in the clinical laboratory. J. Clin. Microbiol. 30:1262-1266.

2. Allen, D. A., B. Austin, and R. R. Colwell. 1983. Aeromonas media. A new species isolated from river water. Int. J. Syst. Bacteriol. 33:599-604.

3. Altwegg, M., M. W. Reeves, R. Altwegg-Bissig, and D. J. Brenner. 1991. Multilocus enzyme analysis of the genus Aeromonas and its use for species identification. Zentralbl. Bakteriol. 275:28-45.

4. Altwegg, M., A. G. Steigerwalt, R. Altwegg-Bissing, J. Lüthy-Hottenstein, and D. J. Brenner. 1990. Biochemical identification of Aeromonas genospecies isolated from humans. J. Clin. Microbiol. 28:258-264.

5. Austin, D. A., D. McIntosh, and B. Austin. 1989. Taxonomy of fish associated Aeromonas spp., with the description of Aeromonas salmonicida subsp. smithia subsp. nov. Syst. Appl. Microbiol. 11:277-290.

6. Carnahan, A. M., T. Chakraborty, G. R. Fanning, D. Verma, A. Ali, J. M. Janda, and S. W. Joseph. 1991. Aeromonas trota sp. nov., an ampicillinsusceptible species isolated from clinical specimens. J. Clin. Microbiol. 29: 1206-1210.

7. Carnahan, A. M., G. R. Fanning, and S. W. Joseph. 1991. Aeromonas jandaei (formerly genospecies DNA group $9 \mathrm{~A}$. sobria), a new sucrose-negative species isolated from clinical specimens. J. Clin. Microbiol. 29:560-564.

8. Carnahan, A. M., and S. W. Joseph. 1993. Systematic assessment of geographically and clinically diverse aeromonads. Syst. Appl. Microbiol. 16:7284.

9. Doestch, R. N. 1981. Determinative methods of light microscopy, p. 26-27. In P. Gerhardt, R. G. E. Murray, R. N. Costilow, E. W. Nester, W. A. Wood, N. R. Krieg, and G. B. Phillips (ed.), Manual of methods for general bacteriology. American Society for Microbiology, Washington, D.C.

10. Esteve, C. 1993. Taxonomía numérica de las cepas de Aeromonas móviles, p. 107-130. In Servicio de Publicaciones de la Universitat de València (ed.), Bacterias patógenas de la anguila europea Anguilla anguilla, L.: taxonomía y factores relacionados con su virulencia. Ph. D. thesis. E.T.D.S.A., Barcelona, Spain.

11. Ferragut, C., and H. Leclerc. 1976. Etude comparative des méthodes de détermination du $T_{m}$ de l'ADN bactérien. Ann. Microbiol. (Paris) 127:223 235.

12. Gauthier, M. J., J. Aubert, and M. Aubert. 1982. Numerical analysis of the heterotrophic bacterial fiora from necrosis of marine fish. Rev. Int. Oceanogr. Med. 66/67:3-32.

13. Hickman-Brenner, F. W., G. R. Fanning, M. J. Arduino, D. J. Brenner, and J. J. Farmer III. 1988. Aeromonas schubertii, a new mannitol-negative species found in human clinical specimens. J. Clin. Microbiol. 26:1561-1564.

14. Hickman-Brenner, F. W., K. L. MacDonald, A. G. Steigerwalt, G. R. Fanning, D. J. Brenner, and J. J. Farmer III. 1987. Aeromonas veronii, a new ornithine decarboxylase-positive species that may cause diarrhea. J. Clin. Microbiol. 25:900-906.

15. Holding, A. J., and J. G. Collee. 1971. Routine biochemical tests. Methods Microbiol. 6A:2-32.

16. Hsu, T. C., W. D. Waltman, and E. B. Shotts. 1981. Correlation of extracellular enzymatic activity and biochemical characteristics with regard to virulence of Aeromonas hydrophila. Dev. Biol. Stand. 49:101-111.

17. Janda, J. M., and E. J. Bottone. 1981. Pseudomonas aeruginosa enzyme profiling: predictor of potential invasiveness and use as an epidemiological tool. J. Clin. Microbiol, 14:55-60.

18. Janda, J. M., and R. P. Kokka. 1991. The pathogenicity of Aeromonas strains relative to genospecies and phenospecies identification. FEMS Microbiol. Lett. 90:29-34.

19. Johnson, J. L. 1994. Similarity analysis of DNAs, p. 655-682. In P. Gerhardt, R. G. E. Murray, W. A. Wood, and N. R. Krieg (ed.), Methods for general and molecular bacteriology. American Society for Microbiology, Washington, D.C.

20. Kämpfer, P., and M. Altwegg. 1992. Numerical classification and identification of Aeromonas genospecies. J. Appl. Bacteriol. 72:341-351.

21. Kitamikado, M., and Y.-Z. Lee. 1975. Chondroitinase-producing bacteria in natural habitats. Appl. Microbiol. 29:414-421. 
22. Kitaura, T., S. Doke, I. Azuma, M. Imaida, K. Miyano, K. Harada, and E. Yabuuchi. 1983. Halo production by sulfatase activity of Vibrio vulnificus and Vibrio cholerae $\mathrm{O} 1$ on a new selective sodium dodecyl sulfate-containing agar medium: a screening marker in environmental surveillance. FEMS Microbiol. Lett. 17:205-209.

23. Kluyver, A. J., and C. B. van Niel. 1936. Prospects for a natural system of classification of bacteria. Zentralbl. Bakteriol. Parasitenkd. Infektionskr. Hyg. Abt. 1 Orig. Reihe A 94:369-403.

24. Lee, J. V., and T. J. Donovan. 1985. Vibrio, Aeromonas and Plesiomonas. Soc. Appl. Bacteriol. Tech. Ser. 21:13-33.

25. Lee, J. V., P. Sheread, A. L. Furniss, and T. N. Bryant. 1981. Taxonomy and description of Vibrio fluvialis sp. nov. (synonym group F vibrios, group EF6). J. Appl. Bacteriol. 50:73-94.

26. Marmur, J. 1961. A procedure for the isolation of deoxyribonucleic acid from microorganisms. J. Mol. Biol. 3:208-218.

27. Marmur, J., and P. Doty. 1962. Determination of the base composition of deoxyribonucleic acid from its thermal denaturation temperature. J. Mol. Biol. 5:109-118.

28. Martínez-Murcia, A. J., C. Esteve, E. Garay, and M. D. Collins. 1992. Aeromonas allosaccharophila sp. nov., a new mesophilic member of the genus Aeromonas. FEMS Microbiol. Lett. 91:199-206.

29. Oliver, J. D., J. E. Wear, M. B. Thomas, M. Warner, and K. Linder. 1986. Production of extracellular enzymes and cytotoxicity by Vibrio vulnificus. Diag. Microbiol. Infect. Dis. 5:99-110.

30. Owen, R. J., and L. R. Hill. 1979. The estimation of base compositions, base pairing and genome size of bacterial deoxyribonucleic acids, p. 217-298. In F. A. Skinner and D. W. Lovelock (ed.), Identification methods for microbiologists, 2nd ed. Academic Press, Inc., London.

31. Owen, R. J., and D. Pitcher. 1985. Current methods for estimating DNA base composition and levels of DNA-DNA hybridization, p. 67-93. In M. Goodfellow and E. Minnikin (ed.), Chemical methods in bacterial systematics. Academic Press, Inc., London.

32. Popoff, M. 1984. Genus III. Aeromonas Kluyver and van Niel 1936, $398^{\text {AL }}$, p. 545-548. In N. R. Krieg and J. G. Holt (ed.), Bergey's manual of systematic bacteriology, vol. 1. The Williams \& Wilkins Co., Baltimore.

33. Popoff, M., and M. Véron. 1976. A taxonomic study of the Aeromonas hydrophila-Aeromonas punctata group. J. Gen. Microbiol. 94:11-22.
34. Popoff, M. Y., C. Coynault, M. Kiredjian, and M. Lemelin. 1981. Polynucleotide sequence relatedness among motile Aeromonas species. Curr. Microbiol. 5:109-114.

35. Reed, M. J., and M. Müench. 1938. A simple method for estimating fifty percent endpoints. Am. J. Hyg. 27:493-497.

36. Reichenbach, H., and M. Dworkin. 1981. The order Cytophagales (with addenda on the genera Herpetosiphon, Saprospira and Flexithrix), p. 356-379. In M. P. Starr, H. Stolp, H. G. Trüper, A. Balows, and H. G. Schlegel (ed.) The prokaryotes, vol. 1. Springer-Verlag, Berlin.

37. Santos, Y., A. E. Toranzo, J. L. Barja, T. P. Nieto, and T. G. Villa. 1988. Virulence properties and enterotoxin production of Aeromonas strains from fish culture systems. Infect. Immun. 56:3285-3293.

38. Schubert, R. H. W., and M. Hegazi. 1988. Aeromonas eucrenophila species nova and Aeromonas caviae, a later and illegitimate synonym of Aeromonas punctata. Zentralbl. Bakteriol. Parasitenkd. Infektionskr. Hyg. Abt. 1 Orig. Reihe A 268:34-39.

39. Schubert, R. H. W., M. Hegazi, and W. Wahling. 1990. Aeromonas enteropelogenes species nova. Hyg. Med. 15:471-472.

40. Schubert, R. H. W. M. Hegazi, and W. Wahling. 1990. Aeromonas ichthiosmia species nova. Hyg. Med. 15:477-479.

41. Smibert, R. M., and N. R. Krieg. 1981. General characterization, p. 409-443. In P. Gerhardt, R. G. E. Murray, R. N. Costilow, E. W. Nester, W. A. Wood N. R. Krieg, and G. B. Phillips (ed.), Manual of methods for general bacteriology. American Society for Microbiology, Washington, D.C.

42. Thornley, M. J. 1960. The differentiation of Pseudomonas from other Gramnegative bacteria on the basis of arginine metabolism. J. Appl. Bacteriol. 23:37-52.

43. Títball, R. W., and C. B. Munn. 1981. Evidence for two haemolytic activities from Aeromonas salmonicida. FEMS Microbiol. Lett. 12:27-30.

44. Wawrzkiewicz, K., J. Bobarzewski, and T. Wolski. 1987. Intracellular keratinase of Trichophyton gallinae. J. Med. Vet. Mycol. 25:261-268.

45. Wayne, L. G., D. J. Brenner, R. R. Colwell, P. A. D. Grimont, O. Kandler, M. I. Krichevsky, L. H. Moore, W. E. C. Moore, R. G. E. Murray, E. Stackebrandt, M. P. Starr, and H. G. Trüper. 1987. Report of the Ad Hoc Committee on Reconciliation of Approaches to Bacterial Systematics. Int. J. Syst. Bacteriol. 37:463-464. 